\title{
KARAKTER TOKOH DALAM NOVEL SOGI KARYA FAIKA BURHAN
}

\author{
Taufik Walhidaya, ${ }^{1}$ Sumiman Udu, ${ }^{2}$ Yunus $^{3}$ \\ pbsi.fkip.uho@gmail.com \\ 1,2,3, Jurusan Pendidikan Bahasa dan Sastra Indonesia, \\ Fakultas Keguruan dan Ilmu Pendidikan, Universitas Halu Oleo \\ Kampus Hijau Bumi Tridharma Anduonohu, Kendari, Indonesia
}

\begin{abstract}
Abstrak
Permasalahan penelitian ini adalah bagaimana karakter tokoh dalam novel "Sogi karya Faika Burhan?"Penelitian ini bertujuan mendeskripsikan karakter tokoh dalam novel Sogi karya Faika Burhan, yang kemudian diharapkan dapat memberi manfaat.Salah satunya dapat memberikan pemahaman kepada pembaca tentang karya sastra mengenai karakter tokoh dalam novel Sogi karya Faika Burhan.Metode penelitian ini adalah metode deskriptif kualitatif.Dikatakan deskriptif kualitatif karena penelitian ini mendeskripsikan data yang dianalisis berupa karakter tokoh yang terdapat dalam novel "Sogi" karya Faika Burhan. Penelitian deskriptif kualitatif adalah penelitian yang ditujukan untuk mendeskripsikan dan menganalisis fenomena-fenomena, peristiwa aktivitas sosial secara alamiah maka dalam penelitian ini, peneliti akan mendeskripsikan tokoh dan karakter tokoh dalam novel sogi, karya Faika Burhan. Penelitian ini tergolong penelitian kepustakaan, karena penelitian ini didukung oleh referensi teks novel maupun sumber buku penunjang lainnya yang mencakup masalah dalam penelitian ini.Penelitian kepustakaan adalah penelitian yang objeknya berupa buku, naskah berbentuk manuskrip, dan internet. Sumber data dalam penelitian ini adalah novel Sogi karya Faika Burhan yang di terbitkan oleh Penerbit Garudhawaca bekerja sama dengan Rumah Bunyi, tahun 2018 terdiri dari 174 halaman. Teknik pengumpulan data dilakukan dengan teknik baca catat.Teknik analisis data dalam penelitian ini menggunakan analisis struktural.Berdasarkan hasil penelitian, dapat disimpulkan bahwa dalam novel Sogikarya Faika Burhan membahas tentang latar dan tokoh.Latar ada tiga yaitu latar tempat, waktu, dan sosial. Tokoh-tokoh yang terdapat dalam novel Sogi karya Faika Burhan, ada dua puluh lima tokoh tetapi peneliti membatasi tokoh-tokoh yang akan di analisis karakternya mengingat hanya empat tokoh yang aktif dan begitu memengaruhi kehidupan tokoh lainya, dan tokoh tokoh tersebut memiliki penceritaan yang sangat menarik untuk di analisis. Adapun keempat tokoh tersebut ialah: tokoh Tenri yang memiliki sfat tokoh tritagonis, Tokoh Linda yang memiliki sifat tokoh protagonis, Tokoh Rosa yang memiliki sifat tokoh antagonis, sedangkan Tokoh Ogi yang memiliki sifat protagonis. Ke empat tokoh tersebut memiliki karakter yang berbeda.
\end{abstract}

Kata Kunci: karakter; tokoh; novel

57 | Jurnal BASTRA (Bahasa dan Sastra), Vol. 5 No.1, Edisi Januari 2020/e-ISSN: 25033875/ http://ojs.uho.ac.id/index.php/BASTRA 


\section{PENDAHULUAN}

\subsection{Latar Belakang}

Karya sastra adalah bentuk kreativitas dalam bahasa yang berisi sederetan pengalaman batin dan imajinasiyang berasal dari penghayatan atas realitas dan non realitas sastrawanya.Karya sastra merupakan suatu bentuk dan hasil pekerjaan seni yang objeknya adalah manusia dan kehidupanya dengan menggunakan bahasa sebagai medianya. Karya sastra merupakan ungkapan batin seseorang melalui bahasa dengan cara penggambaran yang merupakan titian terhadap kenyataan hidup, wawasan pengarang terhadap kenyataan kehidupan, imajinasi murnipengarang yang tidak berkaitan dengan kenyataan hidup (rekaman peristiwa) atau dambaan intuisi pengarang, dan dapat pula sebagai campuran keduanya. (Wicaksono, 2014: 1).

Sastra merupakan salah satu cabang kesenian.Dalam kaitanya dengan masyarakatnya, sastra adalah cerminan kehidupan yang mampu memantulkan nilainilai yang ada dalam masyarakat.Sastra lahir dari perenungan-perenungan penciptaanya tentang kehidupan yang mendalam.kehadiranya bukan dipandang sebagai salah satu realitas sosial budaya.

Karya sastra menyajikan manusia dengan segala sifat dan karakternya melalui peran tokoh. Dengan kata lain manusia dengan karya sastra (novel) adalah subjek yang dihadirkan oleh pengarangnya. Kehadiran manusia dalam karya sastra tidak hanya sebagai pengisi lembaran-lembaran kertas, tetapi juga penentu atau pembawa wawasan berpikir manusia tentang manusia.Namun, tidak jarang masyarakat menganggap bahwa karya sastra dalam hal ini novel adalah karya yang mampu menghibur atau sebagai pengantar tidur belaka.Oleh karena itu, penelitian novel dalam bentuk analisis sangat diperlukan untuk dapat memberi jawaban sekaligus solusi bagi para pembaca agar dapat mengetahui maksud yang terselubung dalam karya sastra tersebut.Novel adalah karangan prosa yang panjang mengandung rangkaian cerita kehidupan seseorang.

Novel adalah salah satu karya sastra yang membahas tentang realitas kehidupan masyarakat.Dalam novel berisi cerita-cerita yang membahas tentang konflik, baik konflik dengan orang lain, konflik dengan lingkungan, dan konflik dengan dirinya sendiri maupun konflik dengan tuhannya.Dengan adanya konflik dalam novel membuat sebuah novel semakin hidup dan seru, sehingga dapat membawa pembaca merasakan setiap peristiwa yang disuguhkan dalam sebuah novel menjadi suatu cerita kehidupan yang merata dan tuntas.

Peneliti menganalisis karakter tokoh dalam novel Sogi karena didalam novel ini banyak menjelaskan perbedaan karakter seorang mahasiswi khususnya dikota Makassar.Novel Sogi ini berkisah tentang persahabatan empat mahasiswi dikota Makassar yakni Tenri, Rosa Ogi, dan Linda adalah empat gadis yang berdarah bugis yang memiliki latar yang berbeda-beda sehingga peneliti tertarik untuk meneliti karakter tokoh dalam novel tersebut.

Terdapat banyak tokoh dalam novel ini, salah satunya Ogi adalah tokoh utama dalam novel ini.Ogi adalah seorang perempuan bugis yang irit berbicara vulgar.Ogi adalah tipe orang yang pemalu, tak pantang menyerah, dan mengargai setiap detik kehidupanya. Ogi berbeda dengan sahabatnya yang lain dia selalu menghindar pada saat teman-tamnya membahas soal pasangan mereka. Ogi adalah Seorang perempuan bugis yang harus dijunjung tinggi, yakni budaya siri (malu).Siri adalah harga diri atau martabat yang dimiliki oleh orang bugis. Seperti yang dilontarkan oleh tokoh Ogi dalam kutipan berikut "Orang Bugis itu hanya hidup dengan siri, jadi tanpa kehormatan, kita hanyalah sampah".Dalam penelitian ini peneliti memilih novel Sogi

\section{8 | Jurnal BASTRA (Bahasa dan Sastra), Vol. 5 No.1, Edisi Januari 2020/e-ISSN: 2503-3875/}

http://ojs.uho.ac.id/index.php/BASTRA 
karya Faika Burhan sebagai objek penelitian karena di dalam novel ini, tokoh-tokohnya berusaha menanamkan pengertian kepada pembaca tentang masalah kehidupan yang terjadi yang disajikan dengan pengkarakteran yang baik serta tidak berbelit-belit sehingga memberikan kemudahan bagi pembaca untuk mengikuti dan memahami cerita dalam novel tersebut. Novel ini juga memiliki tema yang khas dalam sebagian besar karangan Faika Burhan tentang kisah pergaulan bebas sebagai anak kos.

Novel Sogi karya Faika Burhan, berkisah tentang persahabatan empat orang mahasiswi di Kota Makassar. Tenri, Linda, Rosa, dan Ogi adalah empat gadis Bugis yang memiliki latar kehidupan yang berbeda. Meski berbeda, tetapi rasa mereka tersimpul menjadi satu dalam semangat keperempuanan.Rasa keperempuanan itulah yang kemudian menyatukan langkah mereka selama menjalin rutinitas sebagai mahasiswi di sebuah universitas besar di Kota Makassar. Rasa itu berupa nilai-nilai kehidupan seorang perempuan Bugis yang bergelut di kehidupan kota besar.

Selain itu dalam novel Sogi, juga membahas tentang lokalitas daerah Bugis, baik dari segi budaya, kepercayaan, maupun kepribadian dan perwatakan orang Bugis itu sendiri.Salah satu contoh yang menonjol dimunculkan oleh pengarang dalam novel ini adalah tentang kepribadian dan watak kebiasaan orang Bugis.Sejatinya, bahwa kepribadian dan watak orang Bugis adalah orang yang menjunjung tinggi siri' (harga diri) dan martabat.

Sogi merupakan salah satu novel yang cukup menarik untuk diteliti, di samping membahas tentang peran perempuan, novel Sogi juga membahas tentang lokalitas daerah Bugis. Selain itu, alasan peneliti mengambil novel Sogi karya Faika Burhan sebagai bahan penelitian karena novel Sogi karya Faika Burhan banyak memberikan inspirasi bagi para membaca khusunya terhadap perempuan, dengan demikian ada nilai-nilai positif yang dapat diambil dan direalisasikan oleh pembaca dalam kehidupan sehari-hari.

Dalam penelitian ini sengaja dipilih novel Sogi karya Faika Burhan.Karena di dalam novel ini, tokoh-tokoh berusaha menanamkan pengertian kepada pembaca tentang masalah kehidupan yang terjadi yang disajikan dengan pengkarakteran yang baik serta tidak berbelit-belit sehingga memberikan kemudahan bagi pembaca untuk mengikuti dan memahami cerita dalam novel tersebut.

Berdasarkan latar belakang permasalahan di atas, maka penulis memandang perlu untuk mengangkat judul "Karakter Tokoh dalam Novel Sogi Karya Faika Burhan" sebagai bahan penelitian.penulis bermaksud menelaah pada karakter tokoh dalam novel Sogi karya Faika Burhan.

\subsection{Rumusan Masalah}

Berdasarkan latar belakang, maka masalah dalam penelitian ini adalah bagaimana karakter tokoh dalam novel Sogi karya Faika Burhan?

\subsection{Tujuan Penelitian}

Penelitian ini bertujuan mendeskripsikan karakter tokoh yang terkandung dalam novel Sogi karya Faika Burhan.

\subsection{Manfaat Penelitian}

Adapun manfaat yang di harapkan dalam penelitian ini adalah sebagai berikut:

a. Memberi pemahaman kepada pembaca tentang karya sastra mengenai karakter tokoh dalam novel Sogi karya Faika Burhan.

b. Memberi motivasi kepada pembaca untuk senantiasa aktif membaca dan memahami karakter yang ditampilkan dalam karya sastra.

\section{9 | Jurnal BASTRA (Bahasa dan Sastra), Vol. 5 No.1, Edisi Januari 2020/e-ISSN: 2503-3875/}

http://ojs.uho.ac.id/index.php/BASTRA 
c. Memberi pemahaman mengenai langkah menganalisis novel dengan menggunakan pendekatan struktural.

\section{KAJIAN PUSTAKA}

\subsection{Pengertian Novel}

Novel adalah sebuah karya fiksi prosa yang tertulis dan naratif.Biasanya dalam bentuk cerita.Penulis novel disebutnovelis. Kata novel berasal dari italia, "novella" yang berarti "sebuah kisah, sepotong berita" (Redaksi Pm, 2012: 42).

Novel (inggris: novel) dan cerita pendek (disingkat: cerpen; Inggris: short strory) merupakan dua bentuk karya sastra yang sekaligus disebut fiksi. Bahkan, dalam perkembanganya yang kemudian, novel dianggap bersinonim dengan fiksi. (Nugiyantoro, 2015:11). Novel adalah gambaran dari kehidupan dan perilaku yang nyata, dari zaman pada saat novel itu ditulis, (Wellek dan Warren, 1995: 282).

\subsection{Ciri-ciri Novel}

Waluyo dalam (Wicaksono 2014: 122) mengemukakan ciri-ciri yang ada dalam sebuah novel yaitu adanya:(a) perubahan nasib dari tokoh cerita, (b) beberapa episode dalam kehidupan tokoh utamanya, (c) biasanya tokoh utama tidak sampai mati. Tarigan dalam (Wicaksono, 2014: 122) menyatakan bahwa novel mengandung kata-kata berkisar antara 35.000 kata sampai tak terbatas jumlahnya. Dengan kata lain jumlah minimum katakatanya adalah 35.000. jika dipukul rata,satu halaman kertas kuato jumlah barisnya kebawah 35 buah dan jumlah kata dalam satu baris 10 buah maka jumlah kata dalam satu halaman adalah $35 \times 10=350$ buah. Selanjutnya, dapat di maklumi bahwa novel yang paling pendek harus terdiri minimal lebih dari 100 halaman. Lebih lanjut Tarigan dalam (Wicaksono, 2014: 122) menyimpilkan bahwa cirri-ciri novel adalah (1) novel bergantung pada tokoh, (2) novel menyajikan lebih dari satu impresi, (3) novel menyajikan lebih dari satu efek, (4) novel menyajikan lebih dari satu emosi.

\subsection{Unsur-Unsur yang Menbangun Novel}

Sebuah novel merupakan sebuah totalitas, yaitu suatu kesatuan yang bersifat artistik, yang mempunyai bagian-bagian, unsur-unsur yang saling berkaitan satu dengan yang lainsecara erat dan saling menggantungkan.Secara garis besar, unsur novel tersebut dapat dikelompokan menjadi dua bagian, yaitu unsur intrinsik dan ekstrinsik.

Unsur intrinsik adalah unsur-unsur yang membangun karya sastra dari dalam. Unsur-unsur tersebut antara lainalur, penokohan, latar, tema, sudut pandang, gaya bahasa yang kesemuanya secara fungsional berkaitan dengan yang lainya untuk mencapai hakikat dari struktur yang digelarkan oleh pengarang yaitu makna yang menyentuh perasaan pembaca, menarik perhatian pembaca, dan membangkitkan emosional pembaca. Dalam hal inilah novel dianggap sebagai sebuah struktur atau sebuah sistem.

Nurgiyantoro (2013: 30), unsur intrinsik (intrinsic) adalah unsur-unsur yang membangun karya sastra itu sendiri. Unsurunsur inilah yang menyebabkan suatu teks hadir sebagai teks sastra, unsur- unsur yang secara faktual akan di jumpai jika orang membaca karya sastra. Unsur intrinsik sebuah novel adalah unsur-unsur yang (secara langsung) turut serta membangun cerita.Sebagai halnya unsur-unsur yang dimaksud Wellek \& Warren dalam (Nurgiyantoro, 2013: 30) adalah keadaan subjektifitas individu pengarang yang memiliki sikap, keyakinan, dan pandangan hidup yang kesemuanya itu akan memengaruhi karya yang ditulisnya.

\section{0 | Jurnal BASTRA (Bahasa dan Sastra), Vol. 5 No.1, Edisi Januari 2020/e-ISSN: 2503-3875/}

http://ojs.uho.ac.id/index.php/BASTRA 


\subsubsection{Tema}

Menurut Aminuddin dalam (Wicaksono, 2014: 96) kata tema berasal dari bahasa latin 'theme' yang berate 'pokok pikiran' mengartikan tema sebagai tempat meletakan suatu perangkat karena tema merupakan ide yang mendasari suatu cerita sehingga berperanan juga sebagai pangkal tolak pengarang dalam memaparkan fiksi yang dibuatnya. Tema tentusaja memiliki kaitan antara makna dengan tujuan pemaparan prosa fiksi oleh pengarangnya.Untuk memahami tema suatu karya sastra, pembaca terlebih dahulu harus memahami unsur-unsur signifikan yang membangun suatu cerita.

\subsubsection{Alur}

Alur merupakan bagian dari struktur, dari segi cerita dan rekaan.Ketika menguraikan sebuah peristiwa dan perwatakan, baik secara bersama-sama maupun secara sendiri-sendiri, masing-masing membangun alur.

Menurut Wicaksono, (2014: 168) alur merupakan salah satu unsur fiksi yang penting, bahkan bisa jadi orang menganggapnya sebagai unsur fiksi yang paling penting disbanding unsur fiksi yang lain. Alur yang mendasari kisah.

\subsubsection{Latar}

Latar adalah tempat terjadinya peristiwa dalam suatu cerita.Latar belakang fisik, serta unsur tempat dan waktu dalam suatu cerita.Latar menunjukan kepada pembaca kapan dan dimana peristiwa itu terjadi serta mempunyai hubungan dengan eksposisi (Yulisma, 1997: 5).

\subsubsection{Amanat}

Menurut gaffer dalam (Yulisma, 1997: 4) amanat adalah pemecahan tema dan pesan yang ingin disampaikan pengarang kepada pembaca. Amanat atau nasihat merupakan kesan yang ditangkap pembaca.,

\subsubsection{Penokohan atau Perwatakan}

(Karakter Tokoh)

Penokohan dan perwatakan sama halnya seperti alur dan plot, perwatakan dan penokohan juga termaksud unsur intrinsik dalam sebuah cerita atau karya sastra. Menurut Nurgiyantoro (2013: 246-247) mengemukakan bahwa dalam pembicaraan sebuah fiksi, sering dipergunakan istilah-istilah, seperti tokoh dan penokohan, watak dan perwatakan, atau karakter dan karakterisasi secara bergantian dengan menunjuk pengertian yang hampir sama. Penokohan dan karakterisasi sering juga disamakan artinya dengan karakter atau perwatakan menunjuk pada penempatan tokoh-tokoh tertentu dengan watak-watak tertentu dalam sebuah cerita.

Penggunaan istilah "karakter" (character) sendiri dalam berbagai literatur bahasa inggris menyaran pada dua pengertian yang berbeda, yaitu sebagai tokoh-tokoh cerita yang ditampilkan, dan sebagai sikap, keterkaitan, keinginan, emosi, dan prinsip moral yang dimiliki tokoh-tokoh tersebut.Dengan demikian, character dapat berarti 'pelaku cerita' dan dapat pula berarti 'perwatakan'.Antara seorang tokoh dengan perwatakan yang dimilikinya, memang merupakan suatu kepaduan yang utuh. Penyebutan nama tokoh tertentu tidak jarang langsung mengisyaratkan kepada kita perwatakan yang dimilikinya. Stanton dalam (Nurgiyantoro, 2013: 247).

\subsection{Kedudukan Karakter Tokoh dalam Cerita}

Masalah tokoh dan karakter tokoh merupakan suatu hal yang kehadiranya dalam cerita fiksi sangat penting bahkan menentukan, karena tidak mungkin ada suatu karya fiksi tanpa ada tokoh yang bergerak dan pada akhirnya membentuk alur cerita.Tokoh digambarkan dengan ciri-ciri lahir, sifat dan sikap batinya agar wataknya dikenal pembaca.Tokoh-tokoh itu muncul dengan

61 | Jurnal BASTRA (Bahasa dan Sastra), Vol. 5 No.1, Edisi Januari 2020/e-ISSN: 2503-3875/ http://ojs.uho.ac.id/index.php/BASTRA 
watak dengan karakter yang berbedabedasesuai dengan perhatian pengarang.

$$
\text { Menurut Lukens (dalam }
$$

Nurgiyantoro, 2005: 223-224) tokoh-tokoh cerita fiksi hadir sebagai seseorang yang berjati diri, bukan sebagai sesuatu yang tanpa karakter. Justru karena tiap tokoh hadir dengan kualifikasi tersebut kemudian dapat dibedakan antara tokoh yang satu dengan tokoh yang lain. Jadi, aspek kualitas kedirian, jati diri, seorang tokoh penting untuk diketengahkan karena dari situlah pertama-tama dan yang utama identitas tokoh akan dikenali. Kualitas jati diri tidak semata-mata berkaitan dengan ciri fisik, melainkan terlebih berwujud kualitas nonfisik. Oleh karena itu, tokoh dapat dipahami sebagai kumpulan kualitas mental, emosional, dan sosial yang membedakan seseorang orang lain. Jadi aspek nonfisik, mental, emosional, moral, dan sosial dalam hubunganya dengan tokoh cerita dipandang lebih penting daripada sekedar aspek fisik.Dalam realitas kehidupan sehari-hari, berbagai unsur nonfisik lebih menunjukan jati diri seseorang, lebih menjukan ciri karakter seseorang.

\subsection{Metode Mendeskripsikan \\ Karakter Tokoh}

Dalam sebuah novel, para tokoh

harus diperkenalkan secara wajar dan sempurna dengan segala sifat dan kehidupan batinya.Namun, semua orang mengaku bahwa manusia adalah mahkluk yang paling banyak kompleks, sehingga sulit membuat sebuah deskripsi yang lengakap dan memuaskan. Kekompleksanya bukan karena dimensi fisiologisnya atau struktur anatominya yang sukar dianalisis atau digambarkan. Melainkan karena dimensi psikologisnya, yaitu unsur-unsur kewajiban dan akal budinya. Menurut Nurgiyantoro, (2013: 279), ada dua teknik untuk melukiskan dan memperkenalkan tokoh dan karakter tokoh adalah sebagai berikut: a. Teknik Ekspositori

Dalam teknik ekspositori, yang seringjuga disebut sebagai teknis analitis, pelukis tokoh cerita dilakukan dengan memberikan deskripsi, uraian, atau penjelasan secara langsung. Tokoh cerita hadir dan dihadirkan oleh pengarang kehadapan pembaca dengan cara tidak berbelit-belit, melainkan begitu saja dan langsung disertai deskripsi kehadiranya, yang mungkin berupa sikap, sifat, watak, tingkah laku, atau bahkan juga cirri fisiknya.

b. Teknik Dramatik

Penampilan tokoh cerita dalam teknik dramatik, artinya mirip dengan yang ditampilkan pada drama, yaitu dilakukan secara tidak langsung.Maksudnya pengarang tidak mendeskripsikan secara eksplasit sifat dan sikap serta tingkah laku pada tokoh. Pengarang membiarkan para tokoh cerita untuk menunjukan kedirianya sendiri melalui berbagai aktivitas yang dilakukan, baik secara verbal, lewat kata maupun non verbal lewat tindakan atau tingkah laku, dan juga melalui peristiwa yang terjadi. Penampilan tokoh secara dramatik dapat dilakukan lewat sejumlah teknik.

1. Teknik cakapan

Percakapan yang dilakukan oleh tokohtokoh cerita juga biasanya di maksudkan untuk menggambarkan sifat-sifat tokoh yang bersangkutan.

2. Teknik Tingkah Laku

Teknik tingkah laku menyaran pada tindakan yang bersifat nonverbal, fisik.Apa yang dilakukan orang dalam wujudtindakan dan tingkah laku dapat dipandang sebagai menunjukan reaksi tanggapan, sifat dan sikap mencerminkan sifat-sifat pada dirinya.

3. Teknik Pikiran dan Perasaan

Teknik pikiran dan perasaan. Pikiran dan perasaan serta apa yang dipikirkan dan dirasakan oleh tokoh dalam banyak hal akan mencerminkan sifat-sifat kedirianya juga. Bahkan pada hakikatnya, pikiran

62 | Jurnal BASTRA (Bahasa dan Sastra), Vol. 5 No.1, Edisi Januari 2020/e-ISSN: 2503-3875/ http://ojs.uho.ac.id/index.php/BASTRA 
dan perasaanyalah yang kemudian diejawantahkan menjadi tingkah laku werbal dan non verbal.

4. Teknik Arus Kesadaran

Teknik arus kesadaran. Arus kesadaran merupakan sebuah teknik narasi yang berusaha menangkap pandangan dan aliran proses mental tokoh, dimana tanggapan indera bercanpur dengan kesadaran dan ketidaksadaran pikiran, perasaan, ingatan, dan harapan.

5. Teknik Reaksi Tokoh

Teknik reaksi tokoh dimaksudkan sebagai reaksi tokoh terhadap suatu kejadian, masalah, keadaan, kata, dan sikap tingkah laku orang lain, dan sebagainya yang berupa rangsangan dari luar tokoh diri tokoh yang bersangkutan.

6. Teknik Pelukisan Latar

Teknik pelukisan latar.suasana latar sekitar tokoh juga sering dipakai untuk melukiskan kedirianya. pelukisan suasana latar dapat lebih mengintensifkan sifat kedirian tokoh.

7. Teknik Pelukisan Fisik

Teknik pelukisan fisik.keadaan fisik seseorang sering berkaitan dengan keadaan jiwanya, atau paling tidak pengarang sengaja mencari dan memperhubungkan adanya keterkaitan itu. Misalnya, bibir tipis menyaran pada sifat ceriwis dan bawel.Ditinjau dari peranan dan keterlibatan dalam cerita, tokoh dapat dibedakan atas tokoh primer/utama, tokoh sekunder/tokoh bawahan.Tokoh komplementer/tokoh tambahan.

\subsection{Macam-macam Tokoh}

Tokoh- tokoh cerita dalam sebuah cerita fiksi dapat dibedakan kedalam beberapa jenis penamaan itu dilakukan.Berdasarkan perbedaan sudut pandang dan tinjauan tertentu, seorang tokoh dapat saja di kategorikan kedalam beberapa jenis penamaan sekaligus, misalnya sebagai tokoh utama, protagonis, sederhana, dan tokoh berkembang.

\subsubsection{Tokoh Utama dan Tokoh Tambahan}

Berdasarkan perananya atau tingkat penting dalam cerita, tokoh dibedakan menjadi dua yakni tokoh utama adalah tokoh yang diutamakan penceritaanya, baik segi pelaku kejadian maupun yang dikenai kejadian. Karena tokoh utama paling banyak diceritakan dan selalu berhubungan dengan tokoh-tokoh lain, ia sangat menentukan perkembangan plot cerita secara keseluruhan. Ia selalu hadir sebagai pelaku, atau yang dikenai kejadian dan konflik, penting yang mempengaruhi perkembangan plot (Nurgiyantoro, 2013: 258259).

Di pihak lain, pemunculan tokohtokoh tambahan biasanya diabaikan, atau paling tidak, kurang mendapat perhatian. Tokoh utama adalah tokoh yang dibuat sinopsisnya, sedangkan tokoh tambahan biasanya diabaikan karena sinopsis hanya berisi intisari cerita (Nurgiyantoro, 2013: 259).

\subsubsection{Tokoh Protagonis dan \\ Antagonis}

Dilihat dari fungsi penampilan tokoh dalam cerita, dapat dibedakan kedalam tokoh protagonis dan tokoh antagonis.Tokoh protagonis adalah tokoh yang kita kagumi yang salah satu jenisnya secara popular disebut hero tokoh yang merupakan pengejawantahan norma-norma, nilai-nilai yang ideal.Tokoh antagonis merupakan tokoh yang beroposisi dengan tokoh protagonis, secara langsung ataupun tidak langsung (Nurgiyantoro, 2013: 261).

\subsubsection{Tokoh Sederhana dan Tokoh Bulat}

Perbedaan tokoh sederhana dan tokoh bulat dilakukan berdasarkan perwatakanya.Dengan mengkaji dan 
mendalami perwatakan para tokoh dalam suatu cerita fiksi, kita dapat membedakan tokohtokoh yang ada kedalam kategori tokoh sederhana dan tokoh kompleks atau tokoh bulat (Nurgiyantoro, 2013: 264).

\subsubsection{Tokoh Statis dan Tokoh Berkembang}

Menurut Altenbernd \& Lewis (dalam Nurgiyantoro, 2013: 272). Berdasarkan kriteria berkembang atau tidaknya perwatakan tokoh-tokoh cerita dalam sebuah cerita fiksi, tokoh dapat dibedakan kedalam tokoh statis, tidak berkembang dan tokoh berkembang.Tokoh statis adalah tokoh cerita yang secara esensial tidak mengalami perubahan dan atau perkembangan perwatakan sebagai akibat adanya peristiwa-peristiwa yang terjadi.

\subsection{Pendekatan Struktural}

Pendekatan struktural menurut Luxemburg dalam (Wicaksono, 2014: 139) adalah sebuah karya sastra atau peristiwa didalam masyarakat menjadi keseluruhan karena adanya relasi timbal balik antara bagian-bagianya dan antara bagian dan keseluruhan.Struktural adalah adanya anggapan bawa didalam dirinya sendiri karya sastra merupakan suatu struktur yang otonom yang dapat dipahami sebagai suatu kesatuan yang bulat dengan unsur-unsur pembangun yang saling berjalinan.Pradopo dalam (Jabrohim, 2014:69).

Asumsi dasar strukturalisme, sebuah karya sastra merupakan keseluruhan kesatuan makna yang bulat, mempunyai koherensi intrinsik, dalam keseluruhan itu setiap bagian dan unsur memaikan peran yang hakiki, sebaliknya unsur dan bagian mendapat makna seluruhnya dari makna keseluruhan teks Teeuw dalam (Sukada,1993:25).Abrams dalam (Nurgiyantoro,2013:57), mengemukakan bahwa Strukturalisme adalah sebuah totalitas yang dibangun secara koherensi oleh berbagai unsur pembangunya.

Analisis struktural bertujuan membongkar dan memaparkan secermat, seteliti, mendetail dan mendalam mungkin keterkaitan dan keterjalinan semua anasir dan aspek karya sastra yang bersama-sama menghasilkan makana menyeluruh (Teeuw, 2015:106).

Salah satu cara untuk memahami karya sastra ialah dengan pendekatan struktural. Struktural adalah cara berfikir tentang dunia, terutama dalam kaitanya dengan persepsi dan deskripsi struktur. Dunia ini pada hakikatnya merupakan susunan keseluruhan, yang tersusun atas hubunganhubungan benda-benda.Unsur-unsur sebuah kesatuan tidak memiliki makna sendirisendiri.Makna itu baru timbul dari hubungan antar unsur yang terlibat dalam situasi itu.Dengan demikian, maka penuh sebuah kesatuan dapat dipahami bila semua unsur pembentukanyaterintegrasi kedalam sebuah struktur.

\subsection{Penerapan Pendekatan \\ Struktural dalam Mengkaji \\ Karakter Tokoh \\ Pendekatan struktural merupakan} pendekatan yang sering kali digunakan para penelaah sastra dalam menelaah sebuah karya sastra.pendekatan ini memang berusaha untuk objektif dalam melihat karya sastra sebagai suatu sistem itu sangat tergantung kepada nilai komponen-komponen yang ikut terlihat didalamnya.Penerapan pendekatan struktural dalam mengkaji karakter tokoh dapat dimulai dari karakter itu diperkenalkan sampai kepada kedudukan dan fungsi karakter atau perwatakan.Disamping itu, deskripsi karakter harus berhubungan dengan tema, alur, penokohan dan konflik.

METODE DAN TEKNIK PENELITIAN 3.1 Metode dan Jenis Penelitian

64 | Jurnal BASTRA (Bahasa dan Sastra), Vol. 5 No.1, Edisi Januari 2020/e-ISSN: 2503-3875/ http://ojs.uho.ac.id/index.php/BASTRA 


\subsubsection{Metode Penelitian}

Metode yang digunakan dalam
penelitian ini adalah deskriptif
kualitatif.Dikatakan deskriptif kualitatif karena
penelitian ini mendeskripsikan data yang
dianalisis berupa karakter tokoh yang terdapat
dalam novel "Sogi" karya Faika Burhan.
Penelitian deskriptif kualitatif adalah
penelitian yang ditujukan untuk
mendeskripsikan dan menganalisis fenomena-
fenomena, peristiwa aktivitas sosial secara
alamiah maka dalam penelitian ini, peneliti
akan mendeskripsikan tokoh dan karakter
tokoh dalam novel sogi, karya Faika Burhan.

\subsubsection{Jenis Penelitian}

Penelitian ini tergolong penelitian kepustakaan, karena penelitian ini didukung oleh referensi teks novel maupun sumber buku penunjang lainnya yang mencakup masalah dalam penelitian ini.Penelitian kepustakaan adalah penelitian yang objeknya berupa buku, naskah berbentuk manuskrip, dan internet.

\subsection{Data dan Sumber Data}

Data penelitian ini adalah data tertulis berupa teks novel, yang memuat karakter tokoh yang ada dalam novel Sogi Karya Faika Burhan.

Sumber data dalam penelitian ini adalah novel Sogi karya Faika Burhan yang diterbitkan oleh Garudhawaca bekerja sama dengan Rumah Bunyi merupakan cetakan pertama pada tahun 2018, novel Sogi ini terdiri atas 174 halaman.

\subsection{Teknik Pengumpulan Data}

Teknik pengumpulan data yang digunakan dalam penelitian ini adalah sebagai berikut:

a. Teknik baca, yakni membaca novel Sogi karya Faika Burhansecara berulang-ulang untuk mengetahui isi keseluruhan novel dan hal-hal mana saja yang merujuk pada karakter tokoh. b. Teknik catat, yakni teknik mencatat data atau informasi tentang aspek yang merupakan penggambaran dari karakter tokoh dalam novel Sogi karya Faika Burhan yang menjadi objek penelitian.

\subsection{Teknik Analisis Data}

Analisis data dalam penelitian ini menggunakan pendekatan Struktural.Analisis struktural merupakan suatu pendekatan dalam ilmu sastra sebagai suatu kesatuan yang bulat yang unsur-unsurnya mempunyai koherensi. Analisis struktural hendaknya diletakan pada hubungan antara unsur-unsur sehingga totalitas lebih penting dari pada bagian-bagian Teeuw dalam (Apituley, 1991: 5).

Selengkapnya, teknik analisis data yang dimaksudkan dilakukan dengan menggunakan tahapan berikut.

a. Identifikasi data, data yang sudah ada diberi kode (tanda tertentu) sesuai dengan permasalan yang penelitian.

b. Klasifikasi data, yaitu mengelompokkan data.

c. Mengkaji/menganalisis, yaitu penafsiran terhadap data yang telah dikelompokkan.

d. Deskripsi data, yaitu pemaparan data yang telah ditafsirkan kedalam bentuk paparan kebahasaan.

Langkah kerja pendekatan struktural adalah sebagai berikut:

a. Membangun teori struktur sastra sesuai dengan gendre yang diteliti.

b. Peneliti melakukan pembacaan secara cermat, mencatat unsur-unsur struktur yang terkandung dalam bacaan itu.

c. Unsur tema sebaiknya dilakukan terlebih dahulu sebelum membahas unsur lain karena tema akan selalu terkait langsung secara komprehensif dengan unsur lain.

d. Penafsiran harus dilakukan dalam kesadaran penuh akan pentingnya keterkaitan antarunsur. 
HASIL PENELITIAN

\subsection{Karakter Tokoh dalam Novel \\ Sogi, Karya Faika Burhan}

Di dalam novel, tentu selalu ada tokoh yang digunakan untuk menghidupkan cerita. Istilah ' tokoh' merujuk pada pelaku cerita. Sedangkan karakter tokoh yaitu pelukisan gambaran yang jelas tentang seseorang yang ditampilkan dalam sebuah cerita.Jones dalam (Nurgiyantoro, 2010: 165).Tokoh adalah salah satu unsur yang penting dalam suatu novel atau cerita rekaan.Menurut Abrams dalam (Nurgiyantoro, 2010: 165).

\subsubsection{Tokoh Protagonis}

Tokoh protagonis adalah tokoh yang wataknya disukai pembacanya. Biasanya, watak tokoh semacam ini adalah watak yang baik dan positif, seperti dermawan, jujur, rendah hati, membela, cerdik, pandai, mandiri, dan setia kawan dalam kehidupan sehari-hari, jarang ada orang yang mempunyai watak yang seluruhnya baik. Selain kebaikan, orang mempunyai kelemahan (Wicaksono, 2014:227).

\section{Tokoh Ogi}

Dalam Novel Sogi, karya Faika Burhan, tokoh Ogi menempati posisi sebagai tokoh utama, sebab ialah tokoh yang paling di utamakan penceritaanya, dan paling berpengaruh terhadap perkembangan tokohtokoh lain seperti tokoh Tenri, Rosa, dan Linda.

Di awal cerita ia di gambarkan sebagai sosok gadis yang rajin, ia selalu rutin menjenguk anak-anak di taman Cikolatta untuk belajar bersama. Berikut kutipanya:

(Data.1)

"Kak Ogi... mana gitarnya?" mereka mulai bertanya. "Hum...hum kak ndak sempat bawa, lain kali aja nah," "Yaaa kak Ogi payah," ujar salah satu dari mereka."Iya deh, kakak minta maaf ya, soalnya tadi habis ada urusan di tempat lain.

"aiiihh," ujar mereka tak terlalu mendengarkan mereka lalu ramai-ramai menariku memasuki wilayah Cikolatta.Tempat inilah yang selalu mereka tempati belajar bersama jika sore tiba.Pada pagi hari mereka besekolah sepulang sekolah mereka kebanyakan bekerja dengan ikut menggumpulkan barang-barang bekas. Lalu ketika beranjak sore, mereka kembali mengikuti pelajaran bersama di taman belajar yang kami beri nama Cikolatta". (Ogi, hlm. 12-13).

Berdasarkan kutipan di atas tokoh Ogi selain fokus pada kuliahnya, ia juga selalu rutin menjalankan tugasnya sebagai mahasiswi yaitu dengan mengajar anak-anak setiap sore di tempat belajar yaitu taman Cikolata.

\section{Tokoh Linda}

Tokoh Linda di gambarkan sebagai tokoh protagonis yang memiliki sifat periang yang rajin, murah senyum, yang kini ia telah menjalin cinta bersama kekasihnya yaitu Ilham. Ilham selalu menjadi teman jalanya ketika ia pergi membina anak-anak di Cikolatta. Berikut kutipanya:

(Data.1)

$$
\begin{aligned}
& \text { "kak Lindaaa..." Rahul berteriak } \\
& \text { girang ketika melihatku. } \\
& \text { "Halo kakak..." Giring ikutan } \\
& \text { menyapaku dengan } \text { ekspresi } \\
& \text { kaget.Kedua anak itu sontak } \\
& \text { mendekat dan merangkul } \\
& \text { lenganku.Aku pun balas mengusap } \\
& \text { kepala mereka. } \\
& \text { "Kalian ngapain disini?Kalian bolos } \\
& \text { sekolah ya?" } \\
& \text { "Ndak kak, hari ini kami libur sekolah } \\
& \text { karena kakak kelas } 6 \text { lagi ujian } \\
& \text { nasional," } \\
& \text { "Oh.." }
\end{aligned}
$$

66 | Jurnal BASTRA (Bahasa dan Sastra), Vol. 5 No.1, Edisi Januari 2020/e-ISSN: 2503-3875/ http://ojs.uho.ac.id/index.php/BASTRA 
“Mau jalan kote ndak?” tawarku pada mereka.

"Mau kak, mauuu," mereka semakin girang.Lalu aku merangkul mereka menuju lantai satu. (Linda,hlm.41).

Berdasrkan kutipan tersebut, selain menjenguk anak-anak Cikolatta Linda juga merasa senang dengan kehadiran kak Ilham karena ia sebagai teman jalan sekaligus teman yang selalu mengantarku ketika aku mau menjengguk anak anak binaanku.

\subsubsection{Tokoh Tritagonis}

Tokoh Tritagonis adalah pelaku yang membantu dalam suatu cerita, baik tokoh antagonis maupun protagonis.

\section{Tokoh Tenri Di lihat Dari Sisi \\ Baik (Suka menolong, \\ Penyayang, Tegas, Ingin Tahu)}

Tokoh Tenri sosok gadis yang periang, penyayang, tegas, serta memberi nasihat kepada teman-temanya.Ia selau menyemangati teman-teman disekelilingnya ketika mereka menghadapi masalah dalam keluarga. Berikut kutipanya:

(Data.1)

"Kak Tenri, aku lelah! sangat lelah dengan semuanya !!!” Aku diam menatapnya dan menunggu lanjutan ceritanya."Aku benci menjadi diriku," "Sebenarnya apa yang kamu sesali?'"Ia lalu bercerita tentang banyak ayah yang sangat dibencinya karena tak bisa membela dan melindungi ibunya. Ia berharap ingin terlahir kembali sebagai anak laki-laki agar bisa memukuli ayahnya sampai mati. "Indri... tak perlu menunggu kelahiran kedua untuk melindungi ibumu," ia kembali menatapku. "Cukup buat ibumu bangga, buat ia bangga menjadi ibumu," "ibu sudah terlanjur kecewa denganku kak," ia menhapus airmatanya yang kini telah terjatuh. "kamu tau, salah satu kebahagiaan seorang ibu adalah ketika ia merasa sukses membesarkan anaknya. Jika kamu terus seperti ini, ia akan merasa gagal sepanjang hidupnya," Aku menlanjutkan.(Tenri. hlm.34-35).

Berdasarkan kutipan diatas, Tenri yang selalu sayang sama teman-temanya salah satunya Indri yang merupakan teman dekatnya ia adalah salah satu penghuni pondok Sogi. Indri yang mencoba melindungi ibunya dari ayahnya yang jahat suka memukuli ibunya.Indri kepengen ada saudara laki-laki yang melidungi ibunya. Tapi Tenri tidak harus ada anak laki-laki yang harus bisa melindungi seorang ibu seorang gadis bisa juga melindungi ibunya dengan cara-cara yang cukup baik, selalu sayang sama ibu, dan buat ibu bangga sama kita.

\section{Tokoh Tenri Di lihat Dari Sisi Buruknya (suka bicara kasar, haus dengan seks)}

Tokoh tenri selain tegas, suka menolong ia juga digambarkan sebagai sosok gadis yang suka bicara kasar pada teman-temnaya. Berikut kutipanya:

(Data.14)

“Kak Indri teller lagi."Nini mulai melapor dengan suara khasnya yang manja.

“Dia dimana?” tanyaku.

"Tadi pas masuk pagar, dia langsung jatuh di depan kamar ratna, anak-anak itu lalu menggotongnya masuk kekamar ratna," lapor Ila.

"Setan!!!" kataku. Mereka lalu bergegas meninggalkan kamarku (Tenri,hlm.31).

Berdasarkan kutipan diatas, Tenri merasa kesal dengan kelakuan Indri dia cepat 
emosi kalau indri terus yang dihadapinya, ia tidak bisa menahan amarahnya kalu lagi pas ia jengkel dengan tingkah laku Indri.

\subsubsection{Tokoh Antagonis}

Tokoh Antagonis adalah tokoh yang wataknya dibenci pembacanya. Tokoh ini biasanya digambarkan sebagai tokoh yang berwatak buruk dan negative, seperti pendendam, culas, pembohong, mengahalkan segala cara, sombong, iri, suka pamer, dan ambisius. Meskipun demikian, ada juga tokohtokoh antagonis yang bercampur dengan sifatsifat yang baik (Wicaksono, 2014: 227).

Tokoh Rosa adalah tokoh memiliki watak tokoh antagonis buruk. Ia mudah dekat dengan siapa saja. Di awal cerita juga digambarkan sosok gadis genit dan nakal yang berani dengan laki-laki, seperti kekasihnya Henry yang selalu membuatnya bergairah ketika dia sedang memeluk, dan menggodanya. Berikut kutipanya:

(Data.1)

“Apakah gadis pribumi relalu
menggairahkan
kalian?"Tanyaku lagi.Dia tak
menjawab.Bibirnya.Sudah
mengulum bibirku.Sentuhanya
memberiku jawaban. Ah lakon in,
selalu membuat langkahku akan
bertolak arah,
"Nanti mau kemana?"Tanyaku ketika
pelukanya tak bisa kulepas. "ke
hotelya, mau kan?" Bujuknya."
Ndak! Aku harus pulang, tugas-
tugas kuliahku menumpuk ."
mendengar kata hotel tiba-tiba
mataku menyala, aku penasaran
memikirkan apa yang akan terjadi.
Lalu, seperti biasa pikiranku sibuk
mereka-reka kejadian rekaan yang
tak pernah hilang dari rekaanku.
(Rosa,hlm.10).

Berdasarkan kutipan tersebut, tokoh Rosa yang selalu begairah sama kekasihnya kak Henri ia selalu menuruti apa yang Henri mau ia pasrah ia rela mengasihkan harga dirinya sama henri demi melampiaskan nafsunya.

Setelah adegan nakalku dengan Hendri saya memutuskun untuk pulang dipondok untuk bertemu sama teman-temanku karena hari ini saya ada janji sama mereka, turun dari mobilnya aku bergegas memasuki lorong tanpa menoleh lagi. Pikiranku berkelebat kacau, antara senag dan risau.Sampai kapan ini?pikirku berkecamuk sampil memutar gagang pintu kamarku dan La eror sudah berada didalam selonjoran dengan bermacam-macam gaya. Berikut kutipanya: (Data.2)

"Hai...hai..nona ling-ling ni hao ma??" ejek mereka menyambutku aku hanya mengedipkan mata lalu ikut merebahkan diri ditengahtengah mereka. "Oe, lehermu kok merah sekali?"Ujar Linda sambil menarik kerah bajuku kesamping.Mulai lagi dia meledekku.

"Ya iya dong, Henri mengisapku berkali-kali!" jawabku percaya diri."Wuihh...cucok," Respon Linda.Lalu, kami kami semua berkekeh.

"Btw, bausan dia mengajaku kehotel."Kataku mencoleknya.

"Wah mantap dong, jadi kamu dari hotel nih?" Linda menggodaku."Sebenarnya sih mau, aku juga sudah ndak taa....." Katakataku terputus karena tiba-tiba Tenri mencubit lenganku dari samping.

\section{8 | Jurnal BASTRA (Bahasa dan Sastra), Vol. 5 No.1, Edisi Januari 2020/e-ISSN: 2503-3875/}

http://ojs.uho.ac.id/index.php/BASTRA 
“Awasko!" bentaknya galak.Aku dan Linda hanya berkekeh mendengar intruksinya.

"yoipuang indo $\mathrm{ku}$ sayang..." jawabku setengah berteriak.

(Rosa,hlm.10-11).

Dari kutipan diatas, la eror sudah mulai curiga dengan tingkahku yang masih tidak karuan apalagi ketika mereka melihat dibagian leherku ada kemerah-merahan tidak berpikir panjang mereka langsung mengejeku dengan suara rendah. Tapi Rosa tidak peduli dengan apa yang mereka katakana malah ia berbalik menyapa mereka dengan kata-kata nakalya yaitu dengan menggoda temantemanya supaya seperti ia juga.

\section{PENUTUP}

\subsection{Kesimpulan}

Berdasarkan hasil penelitian maka dapat disimpulkan bahwa karakter yang dimiliki setiap tokoh dalam novel ini berbeda-beda perbedaan karakter yang dimiliki para tokoh adalah sebagai berikut.

Tokoh Ogi adalah tokoh yang memiliki sifat protagonis yaitu rajin, mandiri, patuh pada peraturan sosial, rasa ingin tahu, dan lugu. Tokoh Tenri adalah tokoh yang memiliki sifat tritagonis yaitu memiliki watak baik dan buruk.Tokoh Linda adalah tokoh yang memiliki sifat protagonis yaitu memiliki sifat karakter cantik, ramah, murah senyum, meski ramah tapi ia tidak terlalu mudah akrab dengan orang lain.Tokoh Rosa merupakan tokoh yang memiliki sifat antagonis yaitu gadis yang yang haus dengan seks selalu berbicara seronok seenaknya, ia tidak bisa menahan gairahnya ketika sudah bertemu sama lelaki tampan disekitarnya, khususnya Henry.

\subsection{Saran}

Berdasarkan hasil analisis dan kesimpulan dalam penelitian ini, maka peneliti mengajukan saran sebagai berikut:

\section{Bagi Pembaca}

Pembaca karya sastra hendaknya mengambil nilai-nilai positif masingmasing tokoh yang digambarkan melalui karya sastra tersebut, yang kemudian diaplikasikan di kehidupan sehari-hari.

2. Bagi Peneliti Selanjutnya

Penelitian ini bertujuan untuk mencermati dan menganalisis karakter tokoh yang terdapat dalam novel Sogi karya Faika Burhan. Tentu dalam melakukan analisis, peneliti juga menemukan hal-hal menarik lainya, seperti pejuangan tokoh dalam novel Sogi karya Faika Burhan dan belum diangkat untuk dijadikan suatu masalah dalam penelitian, untuk itu diharapkan agar peneliti selanjutnya dalam meneliti dan menganalisis perjuangan tokoh dalam novel Sogi karya Faika Burhan.

\section{DAFTAR PUSTAKA}

Apituley, A Leo. 1991. Struktur Sastra Lisan Tontem Boan.Jakarta: Departemen Pendidikan dan Kebudayaan.

Jabrohim, 2014.Teori Penelitian Sastra. Yogyakarta: Pustaka Pelajar.

Nurgiyantoro, Burhan. 2005. Sastra Anak Pengantar Pemahaman Dunia Anak. Yogyakarta: Gadjah Mada University Press.

Nurgiyantoro, Burhan. 2010. Teori Pengkajian

Fiksi. Yogyakarta: Gadjah Mada University press.

Nurgiyantoro, Burhan. 2013. Teori Pengkajian

Fiksi. Yogyakarta: Gadjah Mada University press.

Redaksi Pm. 2012. Sastra Indonesia Paling Lengkap. Depok: Pustaka Makmur.

Sukada, Made. 1993. Pembinaan Kritik Sastra

Indonesia. Bandung: Angkasa Bandung.

Teeuw, A. 2015.Sastra dan Ilmu Sastra.Bandung: Dunia Pustaka Jaya.

Wicaksono, Andri. 2014. Pengkajian Prosa

Fiksi. Yogyakarta: Garudhawaca.

69 | Jurnal BASTRA (Bahasa dan Sastra), Vol. 5 No.1, Edisi Januari 2020/e-ISSN: 2503-3875/ http://ojs.uho.ac.id/index.php/BASTRA 
Wellek, Rene and Austin Warren. 1995. Teori Kesusastraan, Diterjemahkan dalam bahasa Indonesia oleh Meliani Budianta. Jakarta: Gramedia Pustaka Utama.

Yulisma, 1997.Struktur Sastra Lisan Daerah Jambi. Jakarta: Pusat Pembinaan dan Pengembangan bahasa.

70 | Jurnal BASTRA (Bahasa dan Sastra), Vol. 5 No.1, Edisi Januari 2020/e-ISSN: 2503-3875/ http://ojs.uho.ac.id/index.php/BASTRA 